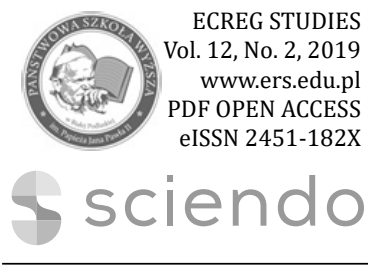

Authors' contribution/

Wkład autorów:

A. Study design/ Zaplanowanie badań

B. Data collection/ Zebranie danych

C. Statistical analysis/ Analiza statystyczna

D. Data interpretation/ Interpretacja danych/

E. Manuscript preparation/ Przygotowanie tekstu

F. Literature search/ Opracowanie piśmiennictwa

G. Funds collection/ Pozyskanie funduszy

\section{ECONOMIC AND REGIONAL STUDIES}

STUDIA EKONOMICZNE I REGIONALNE

ISSN 2083-3725

Volume 12, No. 2, 2019

\title{
THE ROLE OF COOPERATIVE BANK IN THE DEVELOPMENT OF AGRICULTURAL HOLDINGS BASED ON THE EXAMPLE OF THE BIELSK PODLASKI COUNTY
}

\section{ROLA BANKU SPÓŁDZIELCZEGO W ROZWOJU GOSPODARSTW ROLNYCH NA PRZYKŁADZIE POWIATU BIELSK PODLASKI}

\author{
Mikołaj Jalinik $^{1(\mathrm{D}, \mathrm{E})}$, Krzysztof Łukaszuk $^{2(\mathrm{D}, \mathrm{E})}$ \\ ${ }^{1}$ The Faculty of Forestry in Hajnówka, Bialystok University of Technology \\ Zamiejscowy Wydział Leśny w Hajnówce, Politechnika Białostocka \\ ${ }^{2}$ The Cooperative Bank in Bielsk Podlaski \\ Bank Spółdzielczy w Bielsku Podlaskim
}

Jalinik, M., Łukaszuk, K. (2019). The role of cooperative bank in the development of agricultural holdings based on the example of the Bielsk Podlaski county/ Rola banku spółdzielczego w rozwoju gospodarstw rolnych na przykładzie powiatu Bielsk Podlaski. Economic and Regional Studies, 12(2), 146-157.

https://doi.org/10.2478/ers-2019-0014

\section{ORIGINAL ARTICLE}

JEL code: G21, R53, Q12

\section{Summary}

Subject and purpose of work: The aim of the work is to define the importance of banks in the development of agricultural holdings and the role they play in rural environment.

Materials and methods: The relevant material was analysed on the basis of domestic literature concerning a range of banking products offered to natural and legal persons and by the inductivedeductive method

Results: The source of data used for conducting the analyses and drawing conclusions is the information obtained from the Cooperative Bank in Bielsk Podlaski.

Conclusions: 1 . The goal of cooperative banks is to provide the inhabitants of villages with access to banking services, including credits with attractive interest rates. 2 . The services of a cooperative bank are most frequently used by farmers, craftsmen and teachers. 3. In Poland, cooperative banks operate on the basis of: the Foreign Exchange Act, the Payment Services Act, the Act on Freedom of Economic Activities, the Act on the National Bank of Poland, the Act on the National Guarantee Fund, the Law on Bankruptcy and the Rehabilitation Act, as well as on the resolutions of the Management Board of the National Bank of Poland.

Keywords: cooperative banks, agricultural holdings, the Bielsk Podlaski county, bank structure

\section{ORYGINALNY ARTYKUŁ} NAUKOWY

Klasyfikacja JEL: G21, R53, Q12

Zgłoszony:

maj 2019

Zaakceptowany: czerwiec 2019

Tabele: 0

Rysunki: 2

Literatura: 21

\section{Streszczenie}

Przedmiot i cel pracy: Celem opracowania jest określenie znaczenia banków w rozwoju gospodarstw rolnych i roli, jaką spełniają w środowisku wiejskim.

Materiały i metody: Do opracowania materiału zastosowano metodę analizy literatury krajowej dotyczącej oferty produktów bankowych dla osób fizycznych i prawnych oraz metodę indukcyjnodedukcyjna.

Wyniki: Źródłem danych do analizy i wnioskowania są informacje pozyskane z Banku Spółdzielczego w Bielsku Podlaskim.

Wnioski: 1. Celem banków spółdzielczych jest zapewnienie mieszkańcom wsi dostępu do usług bankowych, w tym kredytów o atrakcyjnym oprocentowaniu. 2. Z usług banku spółdzielczego najczęściej korzystają rolnicy, rzemieślnicy i nauczyciele. 3. Banki spółdzielcze działają w oparciu o: ustawę prawo dewizowe, ustawę o usługach płatniczych, ustawę o swobodzie działalności gospodarczej, ustawę o Narodowym Banku Polskim, ustawę o Bankowym Funduszu Gwarancyjnym, ustawę prawo upadłościowe i naprawcze, a także uchwały Zarządu Narodowego Banku Polskiego.

Słowa kluczowe: banki spółdzielcze, gospodarstwa rolne, powiat Bielsk Podlaski, struktura banku

Address for correspondence/ Adres korespondencyjny: prof. nadzw. dr hab. inż. Mikołaj Jalinik (ORCID 0000-0001-6748-3877), Zamiejscowy Wydział Leśny w Hajnówce, Politechnika Białostocka, ul. Piłsudskiego 8, 17-200 Hajnówka, Poland; phone: +48 85 682-95-00; e-mail: jalinik@op.pl; KrzysztofŁukaszuk, e-mail: krzysztof.lukaszuk@wp.pl

Journal indexed in/ Czasopismo indeksowane w: AGRO; AgEcon Search; Baidu Scholar; BazEkon; CEON; CNKI Scholar; CNPIEC - cnpLINKer; EBSCO Discovery Service; Google Scholar; Index Copernicus ICV 2018: 100,00; J-Gate; KESLI-NDSL; Naviga (Softweco); POL-index; Polish Ministry of Science and Higher Education, 2015-2018: 9 points; Primo Central (ExLibris); QOAM; ReadCube; Summon (Serials Solutions/ProQuest); TDNet; WanFang Data; WorldCat (OCLC). Copyright: (C) 2019 Pope John Paul II State School of Higher Education in Biała Podlaska, Mikołaj Jalinik, Krzysztof Łukaszuk. All articles are distributed under the terms of the Creative Commons AttributionNonCommercial-ShareAlike 4.0 International (CC BY-NC-SA 4.0) License (http://creativecommons.org/licenses/by-nc-sa/4.0/), allowing third parties to copy and redistribute the material in any medium or format and to remix, transform, and build upon the material, provided the original work is properly cited and states its license. 


\section{Introduction}

The first banking institution in Poland operating in accordance with the principles of cooperation and self-help was founded in 1577 by father Wawrzyniec Białobrzeski, Fundacja Ostrołęcka Taniego Kredytu (Ostrołęka Cheap Credit Foundation). In the 18th century, various institutions operating in accordance with the principles of self-help were established in villages, which, by means of collecting financial or material assets, helped with regard to granting cash loans or support in kind to those in need (Węcławski 2000). Cooperative banking also had its precursors in the late Middle Ages.

It is worth noting that cooperative banking in Poland, as well as around the world was the prototype of the current banking model. The first mentions of such organizations appeared as early as in the Middle Ages. Cooperative banks developed locally - they gathered around them and helped small entrepreneurs, craftsmen and farmers, who could obtain cheaper funds to run their businesses or allocate financial surpluses favourably. Cooperative banks mainly serve clients from market niches, among which one might enumerate: households, agricultural holdings, small and medium-sized enterprises.

The political and social changes that took place after 1989 initiated the creation of foundations of the market economy in Poland and thus formed the basis for a reform of the entire banking system, including the sector of cooperative banking (Zalcewicz 2009).

Cooperative banks are cooperatives that conduct banking activities. Therefore, the legal basis of their organization is the cooperative law of 16 September 1982 (and also the Act of 7 December 2000 "on the functioning of cooperative banks, their affiliation and affiliating banks," also known as the "Millennium" Act) which specifies that a cooperative is a voluntary affiliation of an unlimited number of people with a variable personal composition and a variable members' fund, pursuing in the interests of its members a joint economic activity in accordance with the principles of economic accounting and also capable of conducting social, educational and cultural activities for their benefit (Journal of Laws of 2018, item 1285).

A cooperative bank is one of the legal forms of a bank's activity (alongside a joint stock company and a state-owned enterprise), provided for in the Polish banking law. A cooperative bank is owned by cooperative members (shareholders, members). Cooperative banks currently constitute the largest banking structure in Poland. There are over 550 cooperative banks operating in the country, which altogether have over five thousand branches (

https://www.najlepszekonto.plıWiadomości). Currently, many cooperative banks offer not only the possibility of opening a personal account, obtaining a cheap credit or opening a deposit account, but also of using such products as: a foreign currency account, a savings account, property and personal insurance, Western Union transfers, online and mobile banking, leasing of fixed assets or investment needs, electronic

\section{Wstęp}

Pierwszą instytucją bankową w Polsce działającą na zasadach współdziałania i samopomocy była założona w 1577 r. przez ks. Wawrzyńca Białobrzeskiego Fundacja Ostrołęcka Taniego Kredytu. W XVIII wieku we wsiach zakładane były różne instytucje działające na zasadach samopomocy, które poprzez gromadzenie środków pieniężnych lub rzeczowych pomagały przy udzielaniu pożyczek pieniężnych lub wsparcia w naturze potrzebującym (Węcławski 2000). Spółdzielczość bankowa miała także swoich prekursorów w okresie późnego średniowiecza.

Warto podkreślić, że bankowość spółdzielcza w Polsce, jak i na całym świecie, była pierwowzorem obecnego modelu bankowości. Pierwsze wzmianki o tego typu organizacjach, pojawiły się już w średniowieczu. Banki spółdzielcze rozwijały się lokalnie - skupiały wokół siebie i pomagały małym przedsiębiorcom, rzemieślnikom i rolnikom, którzy mogli pozyskać tańsze środki na prowadzenie swojej działalności lub korzystnie ulokować nadwyżki finansowe. Banki spółdzielcze obsługują przede wszystkim klientów z nisz rynkowych, do których można zaliczyć: gospodarstwa domowe, gospodarstwa rolne, małe i średnie podmioty gospodarcze.

Zmiany polityczne i społeczne, jakie zaszły po roku 1989, zapoczątkowały w Polsce budowę podstaw gospodarki rynkowej i tym samym stanowiły grunt do przeprowadzenia reformy całego systemu bankowego, w tym także sektora spółdzielczości bankowej (Zalcewicz 2009).

Banki spółdzielcze są spółdzielniami, które prowadzą działalność bankową. W związku z tym, podstawą prawną ich organizacji jest prawo spółdzielcze z dnia 16 września 1982 r. (a także ustawa z dnia 7 grudnia 2000 roku „o funkcjonowaniu banków spółdzielczych, ich zrzeszaniu się i bankach zrzeszających”, zwana również ustawą „milenijną”), która określa, że spółdzielnia jest dobrowolnym zrzeszeniem nieograniczonej liczby osób, o zmiennym składzie osobowym i zmiennym funduszu udziałowym, prowadzacym w interesie swoich członków wspólną działalność gospodarczą na zasadach rozrachunku gospodarczego i mogącym prowadzić także na ich rzecz działalność społeczną i oświatowo-kulturalną (Dz. U. z 2018 r. poz. 1285).

Bank spółdzielczy jest jedną z form prawnych działalności banku (obok spółki akcyjnej i przedsiębiorstwa państwowego), przewidzianą $\mathrm{w}$ polskim prawie bankowym. Właścicielami banku spółdzielczego są spółdzielcy (udziałowcy, członkowie). Banki spółdzielcze stanowią obecnie największą strukturę bankową w Polsce. W kraju funkcjonuje ponad 550 banków spółdzielczych, które łącznie posiadają ponad pięć tysięcy placówek (https://www.najlepszekonto.pl/Wiadomości). Obecnie $\mathrm{w}$ wielu bankach spółdzielczych można nie tylko założyć konto osobiste, uzyskać tani kredyt czy otworzyć lokatę, ale można skorzystać z takich produktów jak: rachunek walutowy, rachunek oszczędnościowy, ubezpieczenia majątkowe i osobowe, przekazy Western Union, bankowość internetowa i mobilna, leasing środków trwa- 
signature certificates or POS payment terminals.

The aim of the work is to present the role which cooperative banks serve in rural communities, and mainly in the development of agricultural holdings. The source of data for conducting analyses and drawing conclusions is the information obtained from the Cooperative Bank in Bielsk Podlaski. The preparation of material consisted of analysing the domestic literature concerning the range of banking products offered to natural and legal persons and employing the inductive-deductive method.

\section{Types and tasks of cooperative banks}

During the period of economic and political changes in 1989, it turned out that cooperative banks required significant modernization. This sector was very fragmented, and the entities that created it were in a difficult financial situation. Until the year 1990, cooperative banks were obligatorily affiliated in BGŻ, which was a state-owned cooperative bank. However, in compliance with the regulation of the President of the National Bank of Poland, in 1992 cooperative banks were obliged to join one of the newly established regional affiliating banks or BGŻ. Between the years 1991 and 1993, cooperative banks created three such affiliating institutions: Gospodarczy Bank Wielkopolski SA in Poznań (GBW), Bank Unii Gospodarczej in Warsaw SA (BUG) and Gospodarczy Bank Południowo-Zachodni in Wrocław (GBPZ) (Mikołajczak 1998). Despite the reparative actions and the favourable policy of the National Bank of Poland, at the beginning of the 1990s the situation in the cooperative banking sector was still dramatic. In 1994, the Act on Restructuring Cooperative Banks and BGŻ was formulated, which resulted in a threetier structure of cooperative banking being created in Poland. These ties were formed by:

- cooperative banks;

- regional banks;

- the national bank, whose role was assumed by BGŻ, now transformed into a joint stock company (Krysiak 2006).

Until recently, only two cooperative banks functioned independently, outside of the affiliating structures characteristic of the cooperative banking sector in Poland. These were: Bank Samopomoc Chłopska and Krakowski Bank Spółdzielczy. According to the data of the Polish Financial Supervision Authority (PFSA), at the end of January 2019, 547 cooperative banks operated in Poland: 347 of them were affiliated in BPS SA (308 were part of IPS BPS), 198 were affiliated in SGB-Bank SA (196 were part of IPS SGB) and four of them were independent (Krakowski Bank Spółdzielczy, Bank Spółdzielczy in Brodnica). Among the remaining banks, 39 of them remained outside of the Institutional Protection Scheme (IPS). However, the PSFA is not consistent in this respect, since it mentions two banks operating independently in its report, while in its letter from 18.01.2019 it mentions four such banks: Krakowski Bank Spółdzielczy, Bank Spółdzielczy in Brodnica, Bank Spółdzielczy Rzemiosła in Krakow and łych lub potrzeb inwestycyjnych, certyfikaty podpisu elektronicznego czy terminale płatnicze POS.

Celem opracowania jest przedstawienie roli, jaką spełniają banki spółdzielcze w środowiskach wiejskich, a głównie w rozwoju gospodarstw rolnych. Źródłem danych do analizy i wnioskowania są informacje pozyskane z Banku Spółdzielczym w Bielsku Podlaskim. Do opracowania materiału zastosowano metodę analizy literatury krajowej, dotyczącej oferty produktów bankowych dla osób fizycznych i prawnych oraz metodę indukcyjno-dedukcyjną.

\section{Rodzaje i zadania banków spółdzielczych}

W okresie zmian gospodarczo-ustrojowych w 1989 roku okazało się, że banki spółdzielcze wymagały znacznej modernizacji. Sektor ten był bardzo rozdrobniony, a podmioty, które go tworzyły miały niełatwą sytuację finansową. Do 1990 roku banki spółdzielcze obowiązkowo były zrzeszone w BGŻ, który miał charakter banku państwowo-spółdzielczego. Jednak zgodnie z zarządzeniem Prezesa NBP w 1992 roku banki spółdzielcze zostały zobligowane do przystąpienia do jednego z nowo utworzonych regionalnych banków zrzeszających lub do BGŻ. W latach 1991-1993 banki spółdzielcze stworzyły trzy takie instytucje zrzeszające: Gospodarczy Bank Wielkopolski SA w Poznaniu (GBW), Bank Unii Gospodarczej w Warszawie SA (BUG) oraz Gospodarczy Bank Południowo-Zachodni we Wrocławiu (GBPZ) (Mikołajczak 1998). Mimo działań mających na celu naprawę i przychylnej polityce NBP, sytuacja w sektorze banków spółdzielczych na początku lat 90 . XX wieku wciąż była kryzysowa. W 1994 roku powstała ustawa restrukturyzacji banków spółdzielczych i BGŻ, w wyniku której utworzono trójszczeblową strukturę bankowości spółdzielczej w Polsce. Szczeble te tworzyły:

- banki spółdzielcze;

- banki regionalne;

- bank krajowy, którego funkcję przejął BGŻ, przekształcony w spółkę akcyjną (Krysiak 2006).

Do niedawna jedynie dwa spośród banków spółdzielczych funkcjonowały samodzielnie, poza strukturami zrzeszeń właściwymi dla sektora bankowości spółdzielczej w Polsce. Były to: Bank Samopomoc Chłopska i Krakowski Bank Spółdzielczy. Według danych Komisji Nadzoru Finansowego (KNF) na koniec stycznia 2019 roku w Polsce działało 547 banków spółdzielczych: 347 zrzeszonych w BPS SA (308 uczestniczących w IPS BPS), 198 zrzeszonych w SGB -Banku SA (196 uczestniczących w IPS SGB) oraz cztery samodzielne (Krakowski Bank Spółdzielczy, Bank Spółdzielczy w Brodnicy). Spośród pozostałych banków 39 pozostawało poza instytucjonalnym systemem ochrony, Institutional Protection Scheme (IPS). Jednak KNF nie jest w tym zakresie konsekwentna, gdyż w swoim raporcie wymienia dwa działające samodzielnie banki, podczas gdy w piśmie z 18.01.2019 r. wymienia 4 banki: Krakowski Bank Spółdzielczy, Bank Spółdzielczy w Brodnicy, Bank Spółdzielczy Rzemiosła w Krakowie oraz Warmińsko-Mazurski Bank Spółdzielczy w Piszu (Urząd Komisji Nadzoru Finansowego, Warszawa 2019). 
Warmińsko-Mazurski Bank Spółdzielczy in Pisz (Office of the Polish Financial Supervision Authority, Warsaw 2019).

A cooperative bank is a bank that is a cooperative, which means that it is first of all a bank (a financial institution), and secondly, a cooperative. The owners of such banks are cooperative members. The most important authority in such banks is the annual general meeting, when each member of the cooperative (a shareholder, member) has the possibility of casting one vote, regardless of the number of shares held. In order to become a shareholder in a cooperative bank, one must pay their share (usually a small sum, which will contribute to the equity of the bank) (Dobosiewicz 2011).

Cooperative members are entitled to a share in the bank's profit (the balance sheet surplus). This profit is small and does not constitute the main motive of their activities. The sale of shares does not have the form of a commercial operation, thus an increase in the value of the bank does not allow cooperative members to achieve higher profits. From the above considerations, it may be concluded that the main goal of the operation of a cooperative bank is to provide a cooperative member with access to banking services, including credits and deposits at favourable interest rates. The services of such a bank are often used by farmers, craftsmen, religious organizations and teachers - generally speaking, these are the professional groups, whose access to a credit in commercial banks is made difficult.

The organizational structure of a cooperative bank was based on solutions adopted for cooperatives. The legislator determines in the Banking Law (as is laid down in Article 20a of the Banking Law, which refers to the provisions of Articles 22-22b of the Banking Law, that is, Article 22 - The Supervisory Board and Article 22a - The Management Board), as well as in the Act on the functioning of cooperative banks, which bodies should be the authorities of cooperative banks. Therefore, the provisions of the Act on Cooperative Law apply here:

- The Annual General Meeting - has ownership functions and makes key decisions;

- The Supervisory Board - controls and supervises the activity of a cooperative and should consist of at least 5 persons who are members of the cooperative bank;

The Management Board represents the cooperative externally and manages its activity (Journal of Laws 1982 No. 30 item 210), , it may include persons who are members of the cooperative bank. The composition of the bank's management board equals at least 3 persons (Banking Law, Article 22a and Article 20a).

For many inhabitants of small towns and villages being a member of a cooperative bank is a chance to obtain a credit. Guaranteeing that a cooperative member will receive high-quality service in terms of other banking activities is also of crucial importance. Most cooperative banks operate in small towns, where they are often the only institutions that perform a wide range of banking activities. Cooperative banking plays a greater role than might
Bank spółdzielczy jest to bank będący spółdzielnią, co oznacza, że w pierwszej kolejności jest to bank (instytucja finansowa), a następnie spółdzielnia. Właścicielami takich banków są spółdzielcy. Najistotniejszą władzą w tego rodzaju bankach jest walne zgromadzenie, na którym każdy spółdzielca (udziałowiec, członek) ma możliwość oddania jednego głosu, niezależnie od liczby posiadanych udziałów. Aby zostać udziałowcem banku spółdzielczego, należy wpłacić udział (zwykle niedużą sumę, która będzie zasilać kapitały własne banku) (Dobosiewicz 2011).

Spółdzielcy mają prawo do udziału w zysku banku (nadwyżki bilansowej). Zysk ten jest niewielki i nie stanowi głównego motywu ich działania. Zbyt udziałów nie ma formy operacji handlowej, wobec tego wzrost wartości banku nie pozwala spółdzielcom na osiąganie większych zysków. Z powyższych rozważań można wywnioskować, że główny cel działania banku spółdzielczego to zapewnienie spółdzielcy dostępu do usług bankowych, w tym kredytów i depozytów o atrakcyjnym oprocentowaniu. Z usług takiego banku korzystają często rolnicy, rzemieślnicy, związki wyznaniowe i nauczyciele - ogólnie ujmując, to te grupy zawodowe, które posiadają utrudniony dostęp do kredytu w bankach komercyjnych.

Struktura organizacyjna banku spółdzielczego oparta została na rozwiązaniach, jakie przyjęte zostały dla spółdzielni. Prawodawca ustala w Prawie bankowym (stanowi o tym art. 20a prawa bankowego, który odwołuje się do przepisów art. 22-22b prawa bankowego, czyli art. 22 - rada nadzorcza i art. 22a - zarząd), jak i ustawie o funkcjonowaniu banków spółdzielczych, jakie organy powinny być organami banków spółdzielczych. Dlatego też zastosowanie mają tu przepisy ustawy - Prawo spółdzielcze:

- Walne zgromadzenie - posiada funkcje właścicielskie, podejmuje kluczowe decyzje;

- Rada Nadzorcza - kontroluje i nadzoruje działalność spółdzielni i powinna składać się co najmniej z 5 osób będących członkami banku spółdzielczego;

- Zarząd - reprezentuje spółdzielnię na zewnątrz oraz zarządza jej działalnością (Dz. U. $1982 \mathrm{nr}$ 30 poz. 210), w skład którego mogą wchodzić osoby będące członkami banku spółdzielczego. Skład zarządu banku wynosi minimum 3 osoby (Prawo bankowe, art. 22a i art. 20a).

Członkostwo w banku spółdzielczym jest dla wielu mieszkańców miasteczek i małych miejscowości szansą na otrzymanie kredytu. Zasadnicze znaczenie ma także gwarancja obsługi spółdzielcy w zakresie innych czynności bankowych na wysokim poziomie. Większość banków spółdzielczych działa w małych miasteczkach, gdzie są one często jedynymi placówkami, które realizują szeroki zakres czynności bankowych. Bankowość spółdzielcza odgrywa większą rolę niż wynikałoby to z udziału sektora banków spółdzielczych w masie depozytów i kredytów polskiego systemu bankowego.

Banki spółdzielcze zaliczane są do podmiotów ekonomii społecznej, dlatego też poza działalnością, która wynika z przynależności do sektora bankowego, za swoją misję uważają realizowanie przedsię- 
be inferred from the share of the cooperative banking sector in the totality of deposits and credits in the Polish banking system.

Cooperative banks are classified as entities within the social economy, therefore, apart from activities resulting from the fact that they belong to the banking sector, they also consider pursuing social and cultural undertakings as their mission. They are often involved in initiatives that are important to the local community in which they operate. Cooperative banks mainly support local development through:

- financing projects that are both agricultural and non-agricultural in their nature;

- granting credits for undertakings related to the protection of the natural environment and ecology;

- supporting initiatives in the field of small entrepreneurship, manufacturing, craftsmanship, services, the development of social and technical infrastructure;

- mediation, coordination and monitoring of the cash flow to their customers from the European Union that is allocated for the development of rural areas, thanks to a good knowledge of the local environment, its conditions and problems regarding the financial and economic situation of its clients;

- providing assistance to municipalities and counties in accordance with the principle of territoriality of cooperative banks by means of issuing municipal bonds. It gives these institutions the opportunity to raise capital for various types of investments, their construction or modernization;

- they partially counteract the social exclusion of inhabitants of social communities (Golik 2005).

The activity of cooperative banks for the benefit of the local community is often an expense for the institution. Therefore, from the economic point of view, the above-mentioned initiatives may have a negative impact on the assessment of the financial stability of a cooperative bank. However, from the social point of view, such activities are assessed positively, and taking such actions is associated with the mission of cooperative banks (Golec 2004). Cooperative banks are also one of the important sources of financing agribusinesses, contributing to an increase in the economic activity of inhabitants of villages.

Supporting the development of agricultural holdings by cooperative banks consists, among others, of granting credits for the activities of business entities, keeping bank accounts, carrying out settlements, insurance mediation, servicing municipal budgets, as well as constant cooperation with regional development agencies, employment bureaus, municipal offices in order to undertake joint financial projects in the field of modernizing agriculture, protecting the environment and developing agricultural tourism (Golik 2002). To some extent, cooperative banks participate in solving the problems of unemployment, by stabilizing the local level of employment and non-agricultural business activities. wzięć społeczno-kulturowych. Często angażują się w inicjatywy ważne dla społeczności lokalnej, w której działają. Banki spółdzielcze wspierają głównie rozwój lokalny poprzez:

- finansowanie projektów, które mają charakter rolniczy, ale także i pozarolniczy;

- kredytowanie przedsięwzięć związanych z ochroną środowiska przyrodniczego i ekologią;

- wspieranie inicjatyw z zakresu drobnej przedsiębiorczości, wytwórczości, rzemiosła, usług, rozwoju infrastruktury społecznej oraz technicznej;

- pośredniczenie, koordynowanie i monitorowanie przepływu środków pieniężnych do swoich klientów z Unii Europejskiej, które sa przeznaczane na rozwój obszarów wiejskich, dzięki dobrej znajomości środowiska lokalnego, jego uwarunkowań i problemów na temat sytuacji finansowej i ekonomicznej swoich klientów;

- niesienie pomocy dla gmin i powiatów, zgodnie z zasada terytorialności banków spółdzielczych, poprzez emisję obligacji komunalnych. To daje tym instytucjom możliwość pozyskania kapitału na różnego rodzaju inwestycje, ich budowę lub modernizację;

- częściowo przeciwdziałaja wykluczeniu społecznemu mieszkańców lokalnych społeczności (Golik 2005).

Działalność banków spółdzielczych na rzecz społeczności lokalnej często stanowi koszt dla instytucji. Dlatego też z ekonomicznego punktu widzenia, wyżej wymienione inicjatywy mogą negatywnie wpływać na ocene stabilności finansowej banku spółdzielczego. Jednak ze społecznego punktu widzenia, działalność taka oceniana jest w sposób pozytywny, a podejmowanie działań wiąże się z misją banków spółdzielczych (Golec 2004). Banki spółdzielcze są także jednym z ważnych źródeł finansowania agrobiznesu przyczyniając się do wzrostu aktywności ekonomicznej mieszkańców wsi.

Wspieranie rozwoju gospodarstw rolnych przez banki spółdzielcze polega między innymi na kredy towaniu działalności podmiotów gospodarczych, prowadzeniu rachunków bankowych, przeprowadzaniu rozliczeń, pośrednictwie ubezpieczeniowym, obsłudze budżetów gminnych, a także stałej współpracy $\mathrm{z}$ agencjami rozwoju regionalnego, urzędami pracy, urzędami gmin $\mathrm{w}$ celu podejmowania wspólnych przedsięwzięć finansowych w zakresie modernizacji rolnictwa, ochrony środowiska i rozwoju agroturystyki (Golik 2002). Banki spółdzielcze w pewnym zakresie współuczestniczą w rozwiązywaniu problemów bezrobocia, stabilizując lokalny poziom zatrudnienia oraz w pozarolniczej działalności gospodarczej. 


\section{Activity of the Cooperative Bank in Bielsk Podlaski}

The Cooperative Bank in Bielsk Podlaski was established after the end of World War II at the initiative of the Bielsk branch of the Supervisory Union of Cooperatives of the Republic of Poland established in Lublin. In July 1945, efforts were made to establish a financial institution in Bielsk Podlaski, with the involvement of local farmers, craftsmen and representatives of the intelligentsia. The beginnings of the Bank's activity included granting short-term loans to farmers for purchasing grains, seed potatoes, fodder, agricultural equipment, livestock and for current repairs. The Bank's functions included satisfying the basic economic needs of agriculture and attempting to encourage farmers to use the services of cooperatives. This endeavour was approved by farmers and later also by craftsmen.

Further development of the Bank meant the successive multiplication of its cooperative and private assets, as well as the variety of other functions which it was to perform during the entire period of its activity. In the 1970s, the Bank was entrusted with compiling an inventory of sales of agricultural produce for pension purposes, as well as selling the grounds belonging to the National Land Fund. There also occurred a significant breakthrough in terms of the services provided by the Bank. After the closure of the State Agricultural Bank in Bielsk Podlaski, the Cooperative Bank in Bielsk Podlaski took over the administrative tasks and granted new investment credits for agriculture and craftsmanship - including credits for the construction of houses (information provided by the Cooperative Bank in Bielsk Podlaski).

During the period of transformation, after 1989, the Polish cooperative banks, as well as the Cooperative Bank in Bielsk Podlaski, proved to be a reliable partner in the implementation of many tasks set by the government in the field of developing agriculture and agricultural processing, as well as small and medium enterprises. The Cooperative Bank in Bielsk Podlaski has a legal personality and it is a cooperative which operates on the basis of the Act of 7 December 2000 on the functioning of cooperative banks, their affiliation, and affiliating banks (The Banking Law Act of 29 August 1997, The Cooperative Law Act of 16 September 1982). The Bank was established for an indefinite period. The Bank is affiliated with Bank Polskiej Spółdzielczości S.A. in Warsaw and is a member of the Franciszek Stefczyk Supervisory Union of Cooperative Banks in Warsaw, and, since 2015, it is also a member of the BPS Protection Scheme for the Affiliation of Cooperatives in Warsaw.

Currently, the Bank is the result of the joint work of its members and staff, both in the economic and the material sense. A significant benefit to the Bank's operation is its affiliation with the largest group of cooperative banks in Poland, the BPS group and Bank Polskiej Spółdzielczości S.A. in Warsaw. The affiliation brings together 348 cooperative banks, and the BPS Bank, as a company, is the largest among the affiliating banks. By means of the Cooperative

\section{Działalność Banku Spółdzielczego w Bielsku Pod- laskim}

Bank Spółdzielczy w Bielsku Podlaskim powstał po zakończeniu II wojny światowej z inicjatywy bielskiego przedstawicielstwa utworzonego $\mathrm{w}$ Lublinie Związku Rewizyjnego Spółdzielni Rzeczpospolitej. W lipcu 1945 roku podjęto starania utworzenia w Bielsku Podlaskim instytucji finansowej, z udziałem miejscowych rolników, rzemieślników i przedstawicieli inteligencji. Początki działalności Banku polegały na udzielaniu rolnikom krótkoterminowych pożyczek na zakup ziarna, sadzeniaków, pasz, sprzętu rolniczego, inwentarza żywego oraz na bieżące remonty. Funkcją Banku było zaspokajanie podstawowych potrzeb gospodarczych dla rolnictwa oraz próba zachęcenia rolników do korzystania z usług spółdzielni. Przedsięwzięcie to uzyskało akceptację rolników, a później także i rzemieślników.

Dalszy rozwój Banku, to sukcesywne pomnażanie jego spółdzielczego i prywatnego majątku, jak również różnorodność innych funkcji, jakie przyszło mu pełnić w całym okresie działalności. W latach 70-tych XX wieku powierzono Bankowi ewidencję sprzedaży płodów rolnych do celów emerytalnych oraz sprzedaż gruntów Państwowego Funduszu Ziemi. Nastąpił też istotny przełom $\mathrm{w}$ zakresie świadczonych przez Bank usług. Po likwidacji Państwowego Banku Rolnego w Bielsku Podlaskim, Bank Spółdzielczy w Bielsku Podlaskim przejął administrowanie oraz udzielał nowych kredytów inwestycyjnych na rzecz rolnictwa i rzemiosła - w tym także kredytów na budownictwo mieszkaniowe (Informacje Banku Spółdzielczego w Bielsku Podlaskim).

W okresie transformacji, po 1989 roku polskie banki spółdzielcze, jak również i Bank Spółdzielczy w Bielsku Podlaskim okazały się niezawodnym partnerem $w$ realizacji wielu zadań określonych przez rząd w zakresie rozwoju rolnictwa i przetwórstwa rolnego oraz małych i średnich przedsiębiorstw. Bank Spółdzielczy w Bielsku Podlaskim posiada osobowość prawną i jest spółdzielnią prowadzącą swoją działalność na podstawie ustawy z dnia 7 grudnia 2000 r. o funkcjonowaniu banków spółdzielczych, ich zrzeszaniu się i bankach zrzeszających (ustawa z dnia 29 sierpnia 1997 r. Prawo bankowe, ustawa z dnia 16 września 1982 r. Prawo spółdzielcze). Bank założono na czas nieokreślony. Bank jest zrzeszony z Bankiem Polskiej Spółdzielczości S.A. w Warszawie i jest członkiem Związku Rewizyjnego Banków Spółdzielczych im. Franciszka Stefczyka w Warszawie, a od 2015 roku także członkiem Spółdzielni Systemu Ochrony Zrzeszenia BPS w Warszawie.

Obecnie Bank jest wspólnym dziełem jego członków i załogi zarówno w sensie ekonomicznym, jak i materialnym. Znaczącym atutem w działalności Banku jest zrzeszenie się z najliczniejszą grupą banków spółdzielczych w Polsce, grupą BPS i z Bankiem Polskiej Spółdzielczości S.A. w Warszawie. Zrzeszenie skupia 348 banków spółdzielczych, a Bank BPS, jako spółka jest największym spośród banków zrzeszających. Za pośrednictwem Banku Spółdzielczego w Bielsku Podlaskim, klienci korzystają z efektów 
Bank in Bielsk Podlaski, its clients benefit from the effects of the affiliation (the BPS Group offers financial services in the field of brokerage, factoring, leasing, investment funds, or debt management). Such an affiliation also means the safety of one's finances and the convenience of depositaries.

In December 2015, the Bank joined the BPS Protection Scheme for the Affiliation of Cooperatives. Contributions of the members of the Institutional Protection Scheme (IPS) are allocated for establishing a system of supporting liquidation and solvency within the sector of cooperative banking, which results in strengthening the financial stability of cooperative banks (these institutions have become even safer and more modern). The undertaken activities are part of the process of introducing new regulatory solutions aimed at ensuring the stability of the financial sector in Poland and in Europe.

Cooperative banks usually operate on the territories of municipalities or counties. They shape the structure in a functional way, with a separate credit department, cash and tax department, accounting and settlements, as well as organizational and economic posts (Kudła 2001). Within the organizational structure of the Bank (2018), there appeared a supernumerary organizational division - the audit committee (Journal of Laws 2017, item 1089), whose most important subject of activity is monitoring the process of financial supervision and the efficiency of internal control and risk management systems, as well as internal auditing (Figure 1). The organizational structure shown in Figure 1 is still currently in place.

The Cooperative Bank in Bielsk Podlaski participates in the obligatory deposit guarantee scheme (BFG) and the BPS Affiliation Protection Scheme. The system guarantees the safety of funds entrusted to the Bank and, in the case of a potential non-standard situation, it ensures the full safety of its participants, which is possible due to constantly monitoring the current situation of cooperative banks covered by the system as well as planning preventive and supportive activities within it.

The Bank operates on the territory of the Podlaskie Province, while the Bank's main activity is focused around the territory of the Bielsk and Hajnówka counties. To a certain extent, the Bank offers its services to customers from the Białystok county (including on the territory of Białystok itself - a city with the rights of a county and a province) and, to a limited degree, on the territory of the Siemiatycze county.

The Cooperative Bank's fundamental structure is formed by the Bank's Headquarters in Bielsk Podlaski and 5 branches (Figure 1).

The Bank is a local deposit and credit bank which mainly serves natural persons and farmers, as well as legal persons and other entities which are domestic persons, including micro, small, and medium-sized enterprises. In addition to offering credit, deposit, and settlement services, the Bank also keeps deposit accounts and provides settlement services in foreign currencies. zrzeszenia (Grupa BPS oferuje usługi finansowe w zakresie obsługi maklerskiej, faktoringu, leasingu, funduszy inwestycyjnych, czy zarządzania wierzytelnościami). Takie zrzeszenie, to także bezpieczeństwo zgromadzonych środków i komfort depozytariuszy.

W grudniu 2015 roku Bank przystąpił do Spółdzielni Systemu Ochrony Zrzeszenia BPS. Wpłaty uczestników do Systemu Ochrony Instytucjonalnej (IPS) są przeznaczane na budowę systemu wsparcia płynności i wypłacalności w sektorze bankowości spółdzielczej, co w efekcie umacnia stabilność finansową banków spółdzielczych (instytucje te stały się jeszcze bezpieczniejsze i bardziej nowoczesne). Podjęte działania wpisują się $\mathrm{w}$ proces wprowadzania nowych rozwiązań regulacyjnych, których celem jest zapewnienie stabilności sektora finansowego w Polsce i w Europie.

Banki spółdzielcze działają najczęściej na obszarach gmin lub powiatów. Kształtują strukturę w sposób funkcjonalny, wyróżniając dział kredytów, kasowo-skarbowy, księgowość i rozliczenia oraz stanowiska organizacyjno-ekonomiczne (Kudła 2001). W strukturze organizacyjnej Banku (2018) pojawiła się nieetatowa komórka organizacyjna - komitet audytu (Dz. U. 2017 r. poz. 1089), którego najistotniejszym przedmiotem działalności jest monitorowanie procesu sprawozdawczości finansowej oraz skuteczności systemów kontroli wewnętrznej i systemów zarządzania ryzykiem oraz audytu wewnętrznego (rysunek 1). Struktura organizacyjna przedstawiona na rysunku 1 trwa do chwili obecnej.

Bank Spółdzielczy w Bielsku Podlaskim uczestniczy w obowiązkowym systemie gwarantowania depozytów (BFG) oraz Systemie Ochrony Zrzeszenia BPS. System gwarantuje bezpieczeństwo środków powierzanych Bankowi, a w przypadku ewentualnego wystąpienia sytuacji niestandardowej zapewnia pełne bezpieczeństwo jego uczestników, co jest możliwe dzięki stałemu monitoringowi bieżącej sytuacji banków spółdzielczych objętych systemem oraz zaplanowane w jego ramach działania prewencyjne i wspomagające.

Bank działa na terenie województwa podlaskiego, natomiast główna działalność Banku jest skupiona na obszarach powiatu bielskiego i hajnowskiego. Częściowo Bank prowadzi działalność wśród klientów $\mathrm{z}$ terenu powiatu białostockiego (w tym na terenie Białegostoku - miasta na prawach powiatu i województwa) oraz w nieznacznej mierze na terenie powiatu siemiatyckiego.

Podstawową strukturę organizacyjną w Banku Spółdzielczym tworzy Centrala Banku w Bielsku Podlaskim oraz 5 oddziałów (rysunek 1).

Bank jest lokalnym bankiem depozytowo-kredytowym obsługującym przede wszystkim osoby fizyczne i rolników oraz osoby prawne i inne podmioty będące osobami krajowymi, w tym mikro, małe i średnie przedsiębiorstwa. Oprócz obsługi kredytowej, depozytowej i rozliczeniowej Bank prowadzi także rachunki depozytowe i usługi rozliczeniowe w walutach obcych.

Rok 2018, to kolejny (drugi) rok realizacji założeń strategii działania Banku na lata 2017-2019. War- 


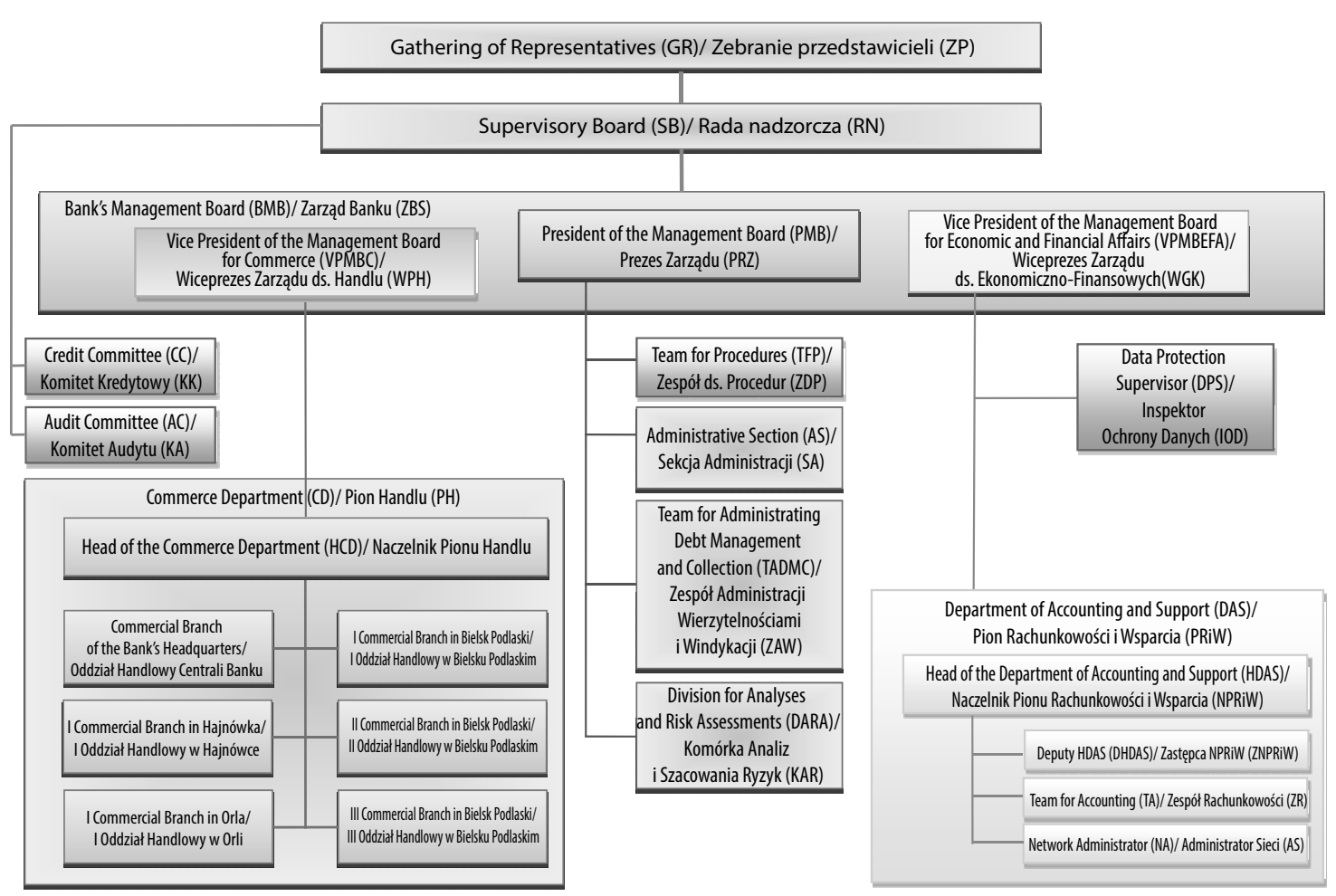

Figure 1. The organizational structure of the Cooperative Bank in Bielsk Podlaski in the years 2017-2019 Rysunek 1. Struktura organizacyjna Banku Spółdzielczego w Bielsku Podlaskim w latach 2017 - 2019

Source: Annex to Resolution No. 12/2018 of the Supervisory Board of the Cooperative Bank in Bielsk Podlaski of May 5, 2018 on approving the organizational structure of the Cooperative Bank in Bielsk Podlaski.

Źródło: Załącznik do Uchwały nr 12/2018 Rady Nadzorczej Banku Spółdzielczego w Bielsku Podlaskim z dnia 5.06 .2018 r. w sprawie zatwierdzenia struktury organizacyjnej Banku Spółdzielczego w Bielsku Podlaskim.

The year 2018 is another (second) year of implementing the Bank's strategy for the years 20172019. The net value of the balance sheet total has reached PLN 147 million (115.7\% of the strategy's implementation), the receivables from the nonfinancial sector have reached the level of PLN 78.7 million $(94.7 \%$ of the strategy's implementation), and the liabilities to the non-financial sector have reached the level of PLN 131.3 million $118.8 \%$ of the strategy's implementation). The Bank has reached the provisions defined in the management and credit risk policy ( $\$ 5$ point 14 of the policy) in the scope of slowing down the growth rate of the loan commitments so that they are adequate to the amount of capital held. Collaboration with neighbouring cooperative banks in the scope of banking credit consortia has been continued. As a result, there occurred a slight decrease in the efficiency of the credit portfolio; compared to December 2017, at the end of 2018 the Bank's interest margin fell from $2.97 \%$ down to $2.96 \%$ (a decrease amounting to 0.01 percentage point), while the operating margin remained at the same level and equalled 2.93\% (information provided by the Cooperative Bank in Bielsk Podlaski).

As predicted, the Monetary Policy Council did not change the basic interest rates in 2018. According to the provisions of the strategy and the financial plan for the year 2018, activities aimed at improving the Bank's financial result were continued, while simultaneously maintaining a moderate credit growth tość sumy bilansowej netto osiągnęła poziom 147 mln. zł (115,7\% wykonania strategii), należności od sektora niefinansowego osiągnęły poziom $78,7 \mathrm{mln}$. zł (94,7\% wykonania strategii), a zobowiązania wobec sektora niefinansowego osiągnęły poziom 131,3 mln. zł $(118,8 \%$ wykonania strategii). Osiągnięto założenie określone polityką zarządzania i ryzykiem kredytowym ( $§ 5$ pkt. 14 polityki) w zakresie wyhamowania dynamiki wzrostu obliga kredytowego adekwatnie do wysokości posiadanych kapitałów. Kontynuowano współpracę z sąsiednimi bankami spółdzielczymi w zakresie kredytowych konsorcjów bankowych. W efekcie nastąpił nieznaczny spadek efektywności portfela kredytowego, w porównaniu do grudnia 2017 roku na koniec roku 2018 marża odsetkowa Banku spadła z poziomu $2,97 \%$ do poziomu $2,96 \%$ (spadek o 0,01 punktu procentowego), natomiast marża operacyjna utrzymała się na tym samym poziomie i wyniosła 2,93\% (Informacje Banku Spółdzielczego w Bielsku Podlaskim).

Zgodnie z przewidywaniami, w 2018 roku Rada Polityki Pieniężnej nie zmieniła podstawowych stóp procentowych. Według założeń strategii oraz planu finansowego na 2018 rok, kontynuowano działania zmierzające do poprawy wyniku finansowego Banku przy jednoczesnej umiarkowanej dynamice kredytów. Poprawiono strukturę przychodów odsetkowych, a celem utrzymania odpowiedniego poziomu wskaźników kapitałowych i rentowności, Bank inwestował środki w zakup bonów pieniężnych NBP oraz 
rate. The structure of income from interest was improved and, in order to maintain the appropriate level of capital ratios and profitability, the Bank invested funds in the purchase of NBP money bills, as well as deposited its financial assets (in compliance with the affiliation agreement) at Bank BPS S.A.

\section{The impact of the Cooperative Bank on the development of agricultural holdings in the Bielsk county}

After Poland's accession to the EU, it ought to be stated that agriculture is still dependent on banks in terms of obtaining foreign capital, apart from the assets transferred to this sector from public funds. The integration of Poland with the European Union, the new market conditions and the intensification of competition force Polish agricultural producers to increase their productivity, modernize and expand fixed assets, as well as to increase the area of farms. This will also enable expanding the scope of activities, reducing unit costs, increasing the competitiveness on the domestic, as well as the European market. One of the most important barriers for the growth and development of Polish agriculture is the deficiency of capital in agricultural holdings, especially in the case of family farms with small areas. This affects the process of their owners making decisions with regard to financing assets using their own capital, whose source lies in the income obtained from running a business. From the above considerations, it may be concluded that the main objective of a cooperative bank's operation is to satisfy the financial needs of cooperative members, including their need for credits (Figure 2).

In addition to granting credits, the Cooperative Bank in Bielsk Podlaski provides services in the field of:

- keeping deposit and settlement accounts (in zlotys and foreign currencies);

- issuing payment cards and performing operations using them, as well as POS terminals;

- granting and confirming bank guarantees;

- mediating with regard to (personal and property) insurance for farmers, private persons and enterprises;

- mediating with regard to leasing services (including those for farmers);

- mediating with regard to certification services (in compliance with the National Clearing House - KIR).

People who use the services of a cooperative bank include farmers, craftsmen and teachers. Generally speaking, these are the professional groups whose access to a credit in commercial banks is made difficult. Currently, being a member of a cooperative bank is not a condition for obtaining a credit, as it is the case, for example in SKOKs (a chain of Polish credit unions). Being a member only gives one the right to a share in the balance surplus and the right to make decisions regarding the way in which the cooperative/bank operates. Access to a bank credit is an important determinant of the development of lokował środki finansowe (zgodnie z umową zrzeszenia) w Banku BPS S.A.

\section{Wpływ Banku Spółdzielczego na rozwój gospo- darstw rolnych w powiecie bielskim}

Po akcesji Polski do UE należy stwierdzić, że rolnictwo jest wciąż zależne od banków w zakresie pozyskania kapitału obcego, nie licząc środków transferowanych do tego sektora z funduszy publicznych. Integracja Polski z Unią Europejską, nowe warunki rynkowe i nasilenie konkurencji, zmuszaja polskich producentów rolnych do podnoszenia wydajności, unowocześniania i powiększania majątku trwałego oraz zwiększania powierzchni gospodarstw. Pozwoli to także zwiększyć skalę działalności, obniżyć koszty jednostkowe oraz podnieść konkurencyjność na krajowym i europejskim rynku. Jedną z istotniejszych barier wzrostu i rozwoju polskiego rolnictwa jest niedostatek kapitału w gospodarstwach rolnych, zwłaszcza w przypadku małoobszarowych gospodarstw rodzinnych. Wpływa to na podejmowanie decyzji przez ich właścicieli o finansowaniu aktywów kapitałem własnym, którego źródłem są dochody uzyskiwane $\mathrm{z}$ prowadzonej działalności. $\mathrm{Z}$ powyższych rozważań można wywnioskować, że główny cel działania banku spółdzielczego, to zaspokojenie potrzeb finansowych spółdzielców, w tym kredytów (rysunek 2).

Poza kredytami, Bank Spółdzielczy w Bielsku Podlaskim świadczy usługi w zakresie:

- prowadzenia rachunków lokacyjnych i rozliczeniowych (w złotych i walutach obcych);

- wydawania kart płatniczych oraz wykonywania operacji przy ich użyciu, a także terminali POS;

- udzielania i potwierdzania gwarancji bankowych;

- pośrednictwa w zakresie ubezpieczeń (osobowych i majątkowych) dla rolników, osób prywatnych i przedsiębiorstw;

- pośrednictwa w zakresie leasingu (w tym także dla rolników);

- pośrednictwa w zakresie usług certyfikacyjnych (w porozumieniu z Krajową Izbą Rozliczeniową).

Z usług banku spółdzielczego korzystają rolnicy, rzemieślnicy i nauczyciele. Ogólnie ujmując, są to grupy zawodowe, które posiadają utrudniony dostęp do kredytu w bankach komercyjnych. Obecnie członkostwo w banku spółdzielczym nie jest warunkiem uzyskania kredytu, tak jak ma to miejsce, np. w SKOK -ach. Członkostwo daje jedynie prawo udziału w nadwyżce bilansowej oraz prawo stanowienia o kształcie funkcjonowania spółdzielni-banku. Dostęp do kredytu bankowego jest istotną determinantą rozwoju podmiotów gospodarczych, w tym także gospodarstw rolnych. Wobec tego, bankowość spółdzielcza odgrywa zdecydowanie większą rolę niż wynikałoby to z udziału sektora banków spółdzielczych w masie 


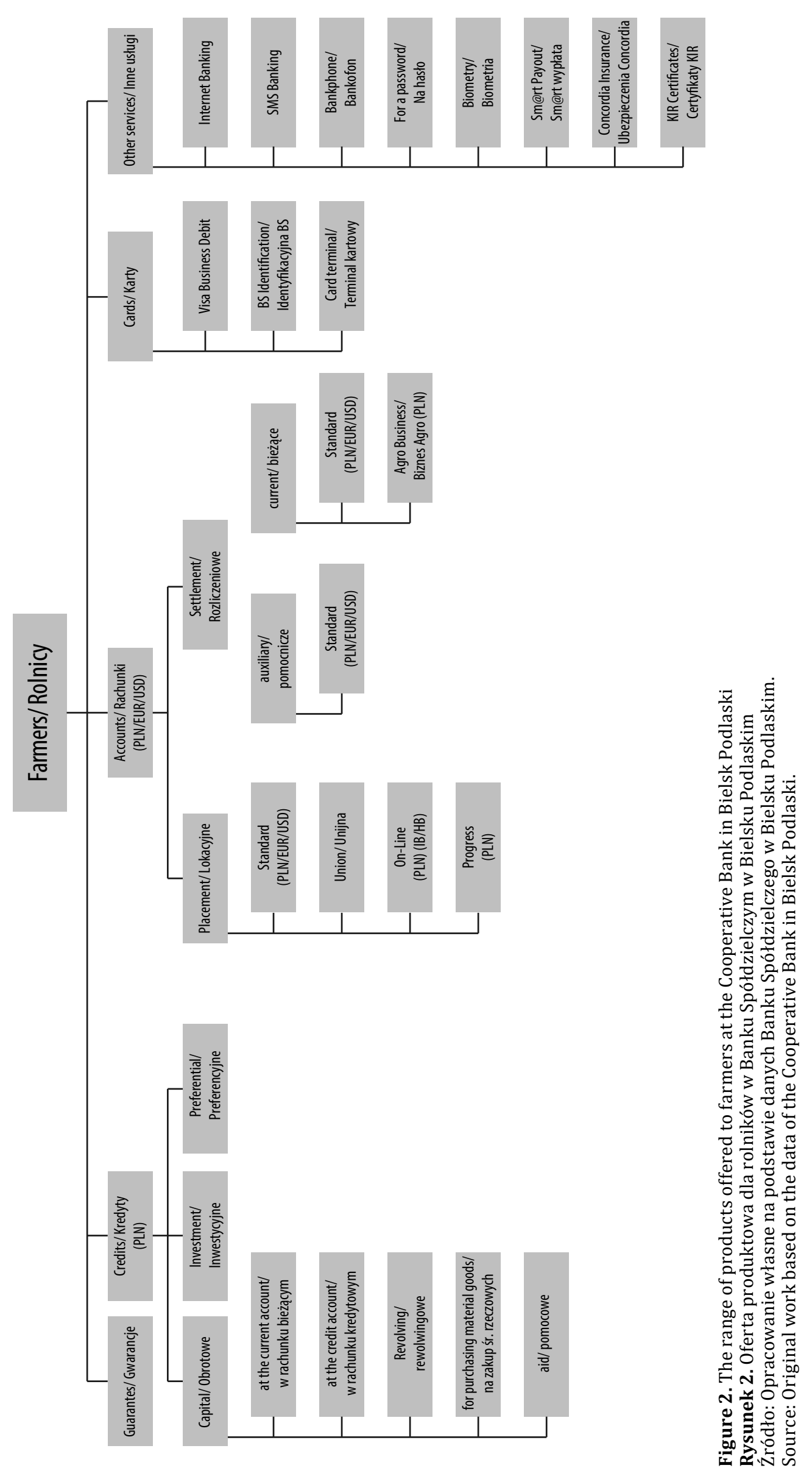


business entities, including agricultural holdings. Cooperative banking plays a greater role than might be inferred from the share of the cooperative banking sector in the totality of deposits and credits in the Polish banking system (Dobosiewicz 2011).

The Polish countryside has many problems that result from the low level of income of most Polish farmers. This also applies to both the overt unemployment in the countryside, as well as the one that is "hidden" at agricultural holdings, the level of education pursuant to its inhabitants, which is lower than in the city, the lack of non-farming workplaces in rural areas. Therefore, financial assets are very important for the development of agricultural holdings (Fedyszak-Radziejowska 2003). The advantages of cooperative banks may be used e.g. in solving the problem of unemployment in the countryside, activating the local community, in the development of entrepreneurship, in shaping the multi-functional development of the countryside, the development and modernization of the rural infrastructure, intensification of agricultural production, environmental protection, development of rural tourism, development of specialization on farms, changes to the agrarian structure and all the other activities serving the economic and social revitalization of the countryside.

Guaranteeing that a cooperative member will be served with regard to other banking activities is also of crucial importance. Cooperative banks are interested in granting credits to agricultural holdings both due to their current financial motivations, as well as the possibility of strengthening a bank's position on the local financial market. In the field of commercial credits, a cooperative bank considers the clients' applications on a case-by-case basis, paying more attention to who the credit recipient is, rather than what is their business plan. In a cooperative bank, individuals whose access to a credit in commercial banks might be made difficult are able to obtain a credit. Under the provisions laid down in this legal regulation, the autonomy of individual cooperative banks has increased significantly, as has the scope and subject of their operation. Cooperative banks have been given the opportunity to perform any banking activities on the territory covering the entire country (Strumiński, Twardowski 2006). This also applies to the Cooperative Bank in Bielsk Podlaski.

\section{Conclusions}

The main goal of the operation of cooperative banks is to provide a cooperative member with access to banking services, including credits at favourable interest rates. Such services are most frequently used by farmers, craftsmen, and teachers. Generally speaking, these are the professional groups, whose access to a credit at commercial banks is made difficult. For many inhabitants of rural areas and small villages, being a member of a cooperative bank is a chance to obtain a favourable credit suited to one's personal financial capabilities.-Guaranteeing depozytów i kredytów polskiego systemu bankowego (Dobosiewicz 2011).

Polska wieś posiada wiele problemów, które wynikają z niskiego poziomu dochodów większości polskich rolników. Dotyczy to także jawnego, jak i „ukrytego" w gospodarstwach rolnych bezrobocia na wsi, niższego niż w mieście poziomu wykształcenia jej mieszkańców, braku pozarolniczych miejsc pracy na obszarach wiejskich. Dlatego też środki finansowe mają duże znaczenia dla rozwoju gospodarstw rolnych (Fedyszak-Radziejowska 2003). Posiadane przez banki spółdzielcze atuty mogą być wykorzystane, np. w rozwiązywaniu problemu bezrobocia wsi, aktywizacji lokalnej społeczności, w rozwoju przedsiębiorczości, w kształtowaniu wielofunkcyjnego rozwoju wsi, rozbudowie i unowocześnianiu infrastruktury wiejskiej, procesach intensyfikacji produkcji rolnej, ochrony środowiska, rozwoju turystki wiejskiej, rozwoju specjalizacji w gospodarstwach rolnych, przemianach struktury agrarnej i wszelkich innych działaniach służących ożywieniu gospodarczemu i społecznemu wsi.

Zasadnicze znaczenie ma także gwarancja obsługi spółdzielcy w zakresie innych czynności bankowych. Banki spółdzielcze są zainteresowane kredytowaniem gospodarstw rolnych, $\mathrm{z}$ uwagi na bieżące motywacje finansowe, jak i możliwość umacniania pozycji banku na lokalnym rynku finansowym. W zakresie kredytów gospodarczych bank spółdzielczy stosuje indywidualne podejście do klientów, zwracając większą uwagę na osobę kredytobiorcy niż na biznesplan. W banku spółdzielczym kredyt mogą otrzymać osoby, które mogłyby mieć utrudniony dostęp do kredytu w banku komercyjnym. Na mocy przepisów zawartych $\mathrm{w}$ tej regulacji prawnej zdecydowanie zwiększyła się autonomia poszczególnych banków spółdzielczych, jak również poszerzeniu uległ zakres oraz przedmiot ich działania. Banki spółdzielcze uzyskały możliwość dokonywania wszystkich czynności bankowych na terytorium obejmującym cały kraj (Strumiński, Twardowski 2006). Dotyczy to także Banku Spółdzielczego w Bielsku Podlaskim.

\section{Podsumowanie}

Głównym celem działalności banków spółdzielczych jest zapewnienie spółdzielcy dostępu do usług bankowych, w tym kredytów o atrakcyjnym oprocentowaniu. Z usług takiego rodzaju najczęściej korzystają rolnicy, rzemieślnicy i nauczyciele. Są to grupy zawodowe, które posiadają utrudniony dostęp do kredytu w bankach komercyjnych. Członkostwo w banku spółdzielczym jest dla wielu mieszkańców obszarów wiejskich i małych miejscowości szansą na uzyskanie atrakcyjnego kredytu dostosowanego do osobistych możliwości finansowych.-Zasadnicze 
that a cooperative member will receive high-quality service in terms of other banking activities is also of crucial importance, in addition to the so-called relativity-a bank knowing a client and their economic and financial situation, as well as the fact that a client identifies with the bank and its staff. znaczenie ma także gwarancja obsługi spółdzielcy w zakresie innych czynności bankowych na wysokim poziomie oraz tzw. relacyjność - znajomość klienta i jego sytuacji ekonomiczno-finansowej przez bank, jak również identyfikacja klienta z bankiem i jego personelem.

\section{References/ Literatura:}

1. Dobosiewicz, Z. (2011). Bankowość. Warszawa: PWE.

2. Golec, M. M. (2004). Spółdzielcze kasy oszczędnościowo-kredytowe na rynku usług finansowych w Polsce. Poznań: Wydawnictwo Wyższej Szkoły Bankowej.

3. Fedyszak-Radziejowska, B. (2003). Wieś i rolnicy wobec procesu integracji z Unią Europejską - wiedza, obawy i nadzieje. Roczniki Naukowe Stowarzyszenia Ekonomistów Rolnictwa i Agrobiznesu, 5(2), 36-50.

4. Golik, D. (2002). Rola banków spółdzielczych w rozwoju obszarów wiejskich Makroregionu Południowo-Wschodniego. Kraków: Wydawnictwo Akademii Ekonomicznej w Krakowie.

5. Golik, D. (2005). Rola banków spółdzielczych w przemianach polskiej wsi w okresie integracji Polski z Uniq̨ Europejską. Kraków: Wydawnictwo Akademii Ekonomicznej w Krakowie.

6. Informacje Banku Spółdzielczego w Bielsku Podlaskim.

7. Komitet audytu powołano na podstawie art. 128 ust. 1, art. 129 ust. 1, ust. 3, ust. 5 i ust. 6 ustawy z dnia 11 maja 2017 r. o biegłych rewidentach, firmach audytorskich oraz nadzorze publicznym (Dz. U. z 2017 r. poz. 1089).

8. Krysiak, I. (2006). Informacja o sektorze spółdzielczym w Polsce. Ekonomia społeczna, 31, 4.

9. Kudła, J. (2001). Struktury organizacyjne banków komercyjnych. Warszawa: TWIGGER.

10. Mikołajczak, R. (1998). Bankowy sektor spółdzielczy wczoraj i dziś. Ruch prawniczy, socjologiczny i ekonomiczny, 3, 4, 243260.

11. Prawo bankowe, art. 22a i art. 20a.

12. Siudek, T. (2007). Systemy bankowości spółdzielczej w wybranych krajach Unii Europejskiej. Zeszyty Naukowe Szkoły Głównej Gospodarstwa Wiejskiego. Ekonomika i Organizacja Gospodarki Żywnościowej, 63, 23-32.

13. Strumiński, D., Twardowski, D. (2006) (red.). Banki spółdzielcze w Polsce. Warszawa: Komisja Nadzoru Bankowego.

14. Ustawa z dnia 16 września 1982 r. Prawo spółdzielcze (Dz. U. 2018 r. poz. 1285).

15. Ustawa z dnia 29 sierpnia 1997 r. Prawo bankowe (Dz. U. 2018 r. poz. 2187 z późn. zm.).

16. Ustawa z dnia 7 grudnia 2000 r. o funkcjonowaniu banków spółdzielczych, ich zrzeszaniu się i bankach zrzeszających (Dz. U. 2018 r. poz. 613).

17. Urząd Komisji Nadzoru Finansowego, Warszawa 2019.

18. Węcławski, J. (2000). System bankowy w Polsce. Rzeszów: MIG.

19. https://www.najlepszekonto.pl > Wiadomości

20. Zalcewicz, A. (2009), Bank Spółdzielczy. Aspekty prawne tworzenia i funkcjonowania. Oficyna Warszawa: Wolters Kluwer Business

21. Zabawa, J. (2015). Banki spółdzielcze jako podmioty ekologicznie odpowiedzialne. Analiza województwa dolnośląskiego. Annales Universitatis Mariae Curie-Skłodowska, Lublin-Polonia, Sectio H, XLIX (4), 727-736. 